\title{
PENDEKATAN SASTRA DALAM PENAFSIRAN AL-QUR'AN (TELAAH PEMIKIRAN BINTI SYATY)
}

\author{
Hamka Hasan \\ UIN Syarif Hidayatullah Jakarta \\ hamkahasan@uinjkt.ac.id
}

\begin{abstract}
Binti Syaty is one of the Islamic scholars who focuses on the study of literature. This approach is also used to interpret the Qur'an - as the most authoritative source in Islam. She applies the literary method of her teacher and husband, Amin al-Khuli. In this paper the author will describe the literary approach used by Binti Syaty in interpreting Islamic sources - namely the al-Qur'an.
\end{abstract}

Kata kunci: Sastra, Islam, al-Qur'an, Binti Syaty

\section{A. Pendahuluan}

Pembacaan kepada Binti Syaty mesti dikaji dengan cara kosmapolitan serta integral. Tak Cuma sekedar mengkaji separuh tulisannya lalu menarik simpulan yang dianggap benar. Seseorang tak bisa dipungkiri pasti selalu terpengaruhi oleh lingkungan di mana ia berada. Sekedar contoh-dan sepele- dengan namanya "Binti Syaty" yang berarti "Putri Pantai" sepertinya sudah menejelaskan sosoknya. Disamping itu background akademisnya sangat mempengaruhinya.

Pengalaman akademisnya di fakultas Sastra "'Ain Asy-Syams" mengharuskannya mengkaji ilmu lunguistik seperti semantik serta hermenetika. Maka sangat wajar jika penafsirannya atas al-Qur'an sangat terpengaruhi oleh pendekatan tersebut. Penafsirannya yang terkesan tidak memanfaatkan bangunan keilmuan yang telah dikembangkan oleh ahli tafsir sebelumnya, menurut penulis, tak berarti bahwa ia menganggap bangunan keilmuan para ulama tidak tepa. Maka dari itu, setiap peneliti yang hendak melakukan kajian atasnya, mesti menelaah betul pandangan yang ia yakini secara benar. Seperti itulah memahami pemikiran seorang tokoh.

Kerja pertama yang mesti dikerjakan oleh akademiki ialah berusaha mengamati beberapa argumentasi yang dilontarkan oleh Binti Syaty yang lalu dimengerti secara tepat. Begitulah langkah "mengkritik" adalah langkah yang cukup lama yang harus dijalankan oleh orang yang ingin mengerti tokoh ini.

Upaya penulis dalam makalah ini, hanya berusaha menampilkan Binti Syaty "apa adanya" kemudian berusaha memberikan "penjelasan" terhadap beberapa pandangannya yang sedikit berbeda dengan ulama tafsir yang lainnya. Sebab saya yakin bahwa dunia yang kita huni ini tidak pernah merumuskan sebuah kata "benar" yang dapat diperpegangi oleh semua makhluk, namun yang kita jumpai justru kata "relatif" dan "perbedaan" yang menjadi bigword dalam dunia akademis. 


\section{B. Biografi Binti Syaty}

Setelah penulis mengkomparasi beberapa kita tafsir dengan karya tafsir Binti Syati, perbedaannya hanya terletak pada perbedaan 'konfigurasi", ${ }^{1}$ namun secara substansinya adalah sama.

Metode sastra ${ }^{2}$ sudah terlihat mulai dari masa sahabat. ${ }^{3}$ Metode tersebut berevolusi menjadi sebuah metode yang terstruktur terjadi pada masa seorang tokoh bernama Amin Khuli. Kemudian estafet keilmuan dilanjutkan oleh muridnya: Ahmad Khalaf Allâh, Binti Syâty, Syukri Muhammad Ayyad, dan Nashr Hamid Abu Zaid. ${ }^{4}$

Binti Syâthi merupakan tokoh kelahiran tahun 1913 M (w. 1998 M) di Provinsi Dumyath, yang terletak di barat delta Nil, Mesir. Sebutannya itu adalah semacam nama pena yang dipakainya. Sebutannya itu juga menjadi salah satu caranya untuk mengenang kampung kelahirannya. Dia menyelesaian pendidian dasar dan menegahnya di kampung halamannya. Lalu pendidika tinginya di Kairo (ibu kota mesir), Universtas Ain Syams, Fakultas Sastra dan memperoleh kedudukan tertingginya dalam akademik, professor sastra dan bahasa arab di tahun 1970. Ia juga adalah seorang professor tamu di beberapa universitas lain.

Metode tafsirnya, secara konsisten ikut dan mengaplikasikan metode gurunya sekaligus suaminya, Amin Khuli.

\section{Tafsir Sastra Binti Syaty}

$$
\text { اقرأ بسم ربك الذى خلقه }
$$

Sungguh heran ayat perdana yang diterima oleh Rasulullah ialah ajakan guna membaca. Bagaimana tidak, perintah membaca tersebut turun kepada orang yang tidak mengenal tradisi membaca, bahkan sering dianggap sebagai orang yang buta huruf. Oleh karena sangat mendesak untuk ditelaah lebih lanjut dibalik "keheranan" itu dengan pendekatan historis ketika al-Qur'an diturunkan. Kita harus berupaya untuk menyajikan realitas itu berupa proses interaksi Muhammad sebagai pembawa risalah kenabian dengan umatnya. Metode tersebut sesuai dibanding dengan pendekatan modern yang sedang dikembangkan oleh orang-orang modernisme. ${ }^{6}$

1 Disinilah kelemahan bagi mereka yang hanya memperdebatkan sesuatu yang hanya bersifat figuratif saja dan mengabaikan hal-hal yang substansial. Dalam hal ini Yusuf Qhardawy memberikan judul pada salah satu bukunya dengan judul "Fikh al-Aulawiyah"

2 J.J.G. Jansen, Diskursus Tafsir al-Qur'an Modern (Yogyakarta: Tiara Wacana Yogya, 1997), 87.

${ }^{3}$ Nur Kholis Setiawan, Al-Qur'an: Ktab Sastra Terbesar (Yogyakarta: eLSAQ Press, 2005), 129.

${ }^{4}$ Yusron, dkk, Studi Kitab Tafsir Kontemporer (Yogyakarta: Teras, 2006), 23. Lihat juga Issa J. Boullata, "Modern Quran Exegesis: A Study of Bint al-Shati' Method," The Muslim Word 64, no. 2 (1974).

5 Abd. Rahman bin Muhammad bin Makhluf ats-Tsa'aly, Mu'asash al'Aly (Beirut: t.p, t.t.), 427. lihat juga dalam: Muhammad bin Muhammad al'Amady abu Sa'ud, Dar Ihya Turats al'Araby (Beiruit: t.p., t.t.), 177.

${ }^{6}$ Aisyah AR, At-Tafsir al-Bayany li al-Quran al-karim, Jilid II (t.tp: Dar al-Ma'arif, t.t), 15. 
Pada dasarnya Binti Syaty ingin mendekati Al-Qur'an dengan metode sejarah. Setiap kesempatan beliau menyarankan agar kata-kata yang ada di al-Qur'an dirujuk artinya kepada "bahasa arab asli”. Ia juga yakin bahwa al-Qur'an sudah bisa menafsirkan dirinya secara mandiri. Pendekatan ini mesti ditelaah kembali karena perkembangan zaman. Tak ada keharusan untuk selalu menjadikan masa lalu sebagai patokan untuk masa depan. Interpretasi Al-Qur'an pada konteks "kemoderenan" merupakan keharusan untuk membumikan al-Qur'an dan ajaran Islam secara umum.

Dengan cara pandang yang ia kembangkan, ia mengapresiasi beberapa hal yakni:

1. Tak memberika ta'wil "objek" pada kata kerja "menciptakan" (ayat kesatu), beliau manafsirkan dengan "hal yang general". Berbeda halnya dengan ayat berikutnya, ia menafsirkan objek penciptaan yang dimaksud dengan manusia karena al-Qur'an diperuntukkan kepada manusia sebagai petunjuk.

2. Ayat itu adalah sebuah penegasan atas Tuhan sebagai Zat yang mengelola seluruh alam raya (Rububiyah) ${ }^{7}$

3. Pencantuman redaksi "manusia" sebagai objek penciptaan Allah dalam ayat ini dikarenakan manusia dapat berkembang secara jasmani-rohani dan perkembangan lainnya. Selain itu manusia adalah objek dari turunnya alQur'an. ${ }^{8}$

Dari sini timbul pertanyaan: "Apa benar hanya manusia saja yang bisa memanfaatkan al-Qur'an sebagai petunjuk? Apa cuma manusia yang wajib beribadah?’

Untuk menjelaskan penafsiran Binti Syaty tersebut, firman Allah dapat menejlaskan hal itu yakni:

$$
\text { وما خلقت الجن والإنس إلا ليعبدون }
$$

Ayat ini menjelaskan bahwa manusia dan jin mesti beribadah hanya kepada Allah.

Interpretasi Binti Syaty di atas, mungkin "tepat" apabila dipahami dengan kasat mata. "Realitas" memberikan pemamahaman kepada kita jika di dunia, cuma manusia yang bisa menjalankan "ibadah", meskipun jin tak luput dari beban tersebut, tapi guna tidak ikut dalam perdebatan yang kontraproduktif, maka manusia jadi sebuah alternatif "yang disajikan".

Dalam menjelaskan ayat ini, Fakhruddin Ar-Razi memberikan tanpilan lain dengan menyatakan bahwa : ayat

$$
\text { اقرأ بسم ربك الذى خلق }
$$

Merupakan syiar kepada manusia bahwasanya setiap membaca Al-Qur'an didahului untuk melafalkan basmalah. Redaksi merupakan ganti dari بسم ربك اللك يسم اله sebab redaksi “Rab” merupakan sifat al-fi'ly Tuhan serta الله merupakan asma Zat-Nya,

\footnotetext{
${ }^{7}$ Aisyah AR, At-Tafsir al-Bayany li al-Quran al-karim, 17.

${ }^{8}$ Aisyah AR, At-Tafsir al-Bayany li al-Quran al-karim.
} 
maka perintah tersebut merupakan perintah guna mengerjakan ibadah berdasarkan sifat fi' $l i$ Tuhan. Menggunakan istilah lain, al-Baidhawy menjelaskan jika "objek" bacaan merupakan: Al-Qur'an.

Pendapat lain yang dikatakan mufasirun, ialah: penampilan redaksi manusia pada ayat tersebut didasarkan atas tujuan bahwa Allah, menciptakan manusia menggunakan kekuasaannya lalu manusia memiliki kemampuan yang memungkinkan untuk mandiri dibanding makhluk lain di alam raya. Allah berfirman:

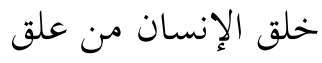

Binti Syaty menolak tafsir ayat ini yang bercerita tentang "geneologi" yang digarap oleh cendekiawan kontemporer. Ia menggarisbawahi jika ayat tersebut bercerita tentang kemampuan Allah, mencipatakan manusia dari darah/sperma/tanah menjadi bentuk lain yang diberikan beban kepadanya amanah sebagaimana tertera dalam al-Qur'an. ${ }^{9}$

Jadi, tak ada argumentasi untuk membenarkan tafsir yang berkata bahwa ada kemungkinan guna menginterpretasikan ayat tersebut sebagai indikasi dalam pengembangan ilmu genetika. Sebab hal yang tak masuk logika, apabila Allah menjelaskan sesuatu yang amat susah diterima logika hambanya, apalagi ketika al-quran itu, diberikan kepada Rasul yang "Ummy"10 yang tak sekalipun belajar ilmu genetika ${ }^{11}$

Hemat penulis, meski begitu, tapi tak bisa disangkal jika dengan nilai yang terdapat di ayat tersebut ternyata amat banyak menyuguhkan ilham kepada kemajuan dunia kedokteran. ${ }^{12}$

Jika kita menelaah sejarah khazanah tafsir klasik serta modern nampak beragam tafsir yang beranekaragam dengan tafsir Binti Syaty, diantaranya : 1) Fakhruddin ar-Razy lebih menyoroti jika ayat tersebut menjelaskan proses penciptaan Nabi Muhammad, disamping itu dalam kitabnya ia menjelaskan jika ayat itu mengumpamakan proses peralihan dari pengakuan atas penyembahan berhala menuju pengakuan atas Allah. Beliau menjelaskan bahwa:

9 Aisyah AR, At-Tafsir al-Bayany li al-Quran al-karim, 19.

${ }^{10}$ Dengan redaksi tersebut, bisa disimpulkan bahwa Beliau lebih menekankan redaksi "Ummy" dengan "buta huruf" (tak tahu baca dan tulis). Sedangkan, ada pendapat yang mengatakan jika redaksi "ummy" artinya penduduk asli. Jika ditelusuri ternyata redaksi tersebut awalnya bermula dari bahasa 'Ibrany" yang artinya 'native speaker' (penduduk asli) atau putra daerah. Maka redaksi 'Ummy" bisa dimengerti jika Nabi Muhammad bukanlah penduduk (bangsa) pembaca, maknanya ia tak berpengalaman membaca kitab. Akan heran ketika Muhammad sebagai nabi, sebagai pedagang sukses, yang kemudian tidak memiliki pengalaman membaca/ mengenal huruf. Makanya redaksi Ummy, mungkin bisa dimengerti jika Nabi Muhammad tak pernah menelaah kitab suci sebelumnya.

${ }^{11}$ Aisyah AR, At-Tafsir al-Bayany li al-Quran al-karim, 18.

12 Sebagai tanda adalah darah yang terdapat dalam badan manusia merupakan hal yang amat menentukan atas pemeriksaan manusia. Orang hamil, AIDS, dan lainnya bisa dicari tahu melalui pemeriksaan darah. Darah menurut ayat tersebut merupakan materi" manusia. 
Untuk analogi evolusi manusia mulai dari hal yang disangka hina yakni darah menjadi hal yang mulia yaitu kalam sebagai citra orang yang memiliki pengetahuan.

Az-Zamakhsyary, menjelaskan jika ayat itu adalah penekanan betapa "agung" penciptaa manusia. $^{13}$

Binti Syaty, mengakhiri ayat itu dnegan mengingatkan jika seluruh ayat yang menjelaskan tentang proses penciptaan manusia tak didapatkan adanya indikasi mengenai ilmu genetika.

Jika ditelaah, ayat itu "tak mungkin" menjelaskan ilmu genetika, lebih lagi kalau tujuan Allah, berfirman seperti itu sebagai perintah guna mengembangkan ilmu genetika. Sebab Al-Qur'an bukanlah "kitab kedokteran", Al-Qur'an menyebutkan dirinya sebagai "hidayah".

Adapun pengembangan ilmu genetika dikemudian hari tak bisa dipisahkan dari proses "Al-Qur'an sebagi Hidayah", terdapat sebagian manusia tertentu yang malahan mendapatkan petunjuk tersebut sesudah banyak bergelut di dunia akademik-ilmiah.

$$
\text { إقرأ وربك الأكرم }
$$

Binti Syati menjelaskan beberapa poin tentang ayat ini seperti yang dijelaskan oleh ahli tafsir pada umumnya, diantranya: 1) Ayat إقرأ yang kesatu dimaksudkan "bacalah untuk diri kamu sendiri" serta dalam ayat itu dijelaskan penyampaian ke manusia lainnya; 2) Ayat kesatu menjelaskan cara-cara belajar dan ayat kedua lebih fokus menjelaskan cara mengajar; 3) Ayat kesatu adalah indikasi guna dilafalkan dalam shalat dan ayat selanjutnya adalah indikasi guna dibaca di luar shalat. ${ }^{14}$

Binti Syati menjelaskan ayat itu memiliki kedekatan makna. Oleh karena itu beliau lebih menggarisbawahi jika paradigma yang sesuai ialah menelaah ayat selaras dengan konteks atau realitas aslinya, yakni: perintah guna membaca yang ditujukan untuk Rasulullah, meskipun ia tak dapat membaca. Indikasi membaca kekedua ialah penjabaran ayat kesatu. ${ }^{15}$

Pada ayat tersebut didapati redaksi: الأكرم, secara detail menjabarkan redaksi itu, yang pada akhirnya menyimpulkan bahwa redaksi itu dinisbatkan pada Allah. Ia berargumen seperti itu, sebab ayat itu adalah satusatunya ayat yang menyebut redaksi alakram dalam bentuk isim tafdhil yang ber- alif lam, beda dengan surah al-hujarat :

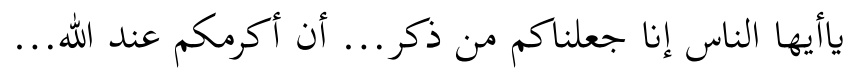

13 Abu al-Qasim Mahmud Al-Zamakhsyari, al-Kassyaf 'an Haqaiq al-Tanzil wa Uyun al-Aqawil (t.tp: tp, 1997).

${ }^{14}$ Aisyah AR, At-Tafsir al-Bayany li al-Quran al-karim, 20.

${ }^{15}$ Aisyah AR, At-Tafsir al-Bayany li al-Quran al-karim. 
Ayat tersebut menjelaskan al-Akram atas diri manusia, sebab redaksi itu langsung di mudhafkan pada dhamir yang ditujukan pada manusia.

$$
\text { الذى علم بالقلم . علم الإنسان ما لم يعلم }
$$

Dalam penafsiran ayat ini, Binty Syati tidak memberikan hal baru. Ia terkesan menjelaskan kembali tafsir mufasir sebelumnya. Ahli tafisr lebih menjelaskan alkalam sebagai hal yang amat bermanfaat dalam rangka mendirikan peradaban. Menggunakan alkalam, maka perkembangan sains akan mengikuti proses yang amat panjang sehinga ilmu tersebut bisa langgeng hingga saat ini.

Tapi di sisi berbeda ia memberi kesimpulan jila "ilmu" yang dimaksud redaksi tersebut yakni ilmu yang digapai manusia melalui usaha. ${ }^{16}$ Maka dari itu tak benar apabila ditanya bahwa "ilmu apa yang diajarkan oleh Allah pada manusia". ${ }^{17}$

Ayat lain untuk dapat menjelaskan ayat ini adalah ayat yang berbunyi:

$$
\text { علم الإنسان ما لم يعلم }
$$

Adalah menjelaskan pemberian Tuhan berupa Ilmu Ladunny, karena ilmu ini adalah ilmu yang diberikan Allah atas hamba-Nya yang diridai-Nya tanpa sebuah kerja keras. Sementara ayat sebelumnya ialah:<smiles>[AlH2][AsH2][AsH2][AsH2]</smiles>

Adalah penjelasan mengenai al-ilmu alkasby, yakni ilmu yang didapat melalui kerja keras yakni al-kalam.

Dengan melihat abstraksi diatas maka dalam "pembahasan" pencarian sebuah ilmu, maka dibagi dua jenis ialah: 1) ilmu ladunny, yakni ilmu yang diperoleh tanpa kerja keras; 2) Ilmu kasby, yakni ilmu yang dimiliki melalui kerja keras. Dengan begitu ayat tersebut menjelaskan bahwa ilmu dimiliki seseorang dengan kerja keras.

Al-qurtuby mejelaskan jika al-kalam yang dimaksud ayat الذى علم بالقلم bahwa Tuhan mengajarkan kepada manusia "tatacara menulis" dengan perantaraan kalam. ${ }^{18}$

Oleh Mufassir yang lain menjelaskan jika tanpa penampilan objek yang mendampingi redaksi "baca" disebabkan memiliki beberapa petunjuk bahwa: 1) Pengetahuan yang akan diajarkan pada manusia ialah semua jenis pengetahuan sampai manusia tak tahu jenis pengetahuan tersebut; 2) Atau karena hanya Allah yang tahu mengenai pengajaran tersebut sesuai dengan kehendaknya.

$$
\text { كلا إن الإنسان ليطغى · أن رآه استغنى }
$$

${ }^{16}$ Dalam hal ini beliau memakai kata-kata "al-Ilmu al-kasby".

${ }^{17}$ Aisyah AR, At-Tafsir al-Bayany li al-Quran al-karim, 24.

dapat dilihat dalam: Muhammad bin Ahmad bin Abi Bakar bin Farh al-Qurtuby Abu Abdillah, al-Jami’ li Ahkam al-Quran (Kairo: Dar sya'by, 1372 H), 120. 
Menurut Binti Syati, banyak kalangan ahli tafsir condong menjelaskan ayat di atas dengan makna sombong karena cinta yang amat berlebih atas hartanya. Manusia menganggap cukup karena memeliki harga yang banyak kemudian lupa atas Allah sebagai yang memberi. ${ }^{19}$

Jika kita ingin objektif dan menelaah ayat maka dapat disimpulkan satu tema besar yakni penciptaan manusia. Karenanya ayat tersebut menjelaskan jika manusia jadi sombong sebab berbangga dengan penciptaannnya. ${ }^{20}$

Ada beberapa mufasir yang meyakini "kesombongan" itu akaibat kemewahan beruap kekayaan yang dimiliki oleh manusia. Salah satu diantaranya adalah al-Baidhawy, Ibnu katsir ${ }^{21}$ At-Thabary ${ }^{22}$.

$$
\text { إن الى ربك الرجعى }
$$

Sesudah menjabarkan redaksi Ar-Ruj'a, beliau mengemukakan kekeliruan mufasir sebelumnya yang condong mengkategorikan redaksi itu sebagai masdar serta ta'nis. Karena ayat tersebut menggarisbawahi "proses pengembalian" itu secara general. Serta tak ان الى ربك mendahului الرجعى sebab penekanan jika "poroses pengembalian” itu pada Allah, ${ }^{23}$

Lebih jauh beliau terangkan bahwa bentuk kata الرجعى merupakan redaksi yang tak didapatkan pada tempat lain dalam al-Quran. Itu mengindikasikan jika tempat kembali tersebut benar-benar menuju Allah. Allah menyertaikan redaksi الرجعى dengan topik mengenai proses penciptaan manusia dari segumpal darah. Kemudian bisa diketahui jika manusia yang dahulu diciptakan dari hal yang hina serta rendah yaitu segumpal darah lalu akan kembali pada Alalh. Manusia bersumber dari Allah, serta kembali pada Allah. ${ }^{24}$

$$
\text { أرأيت الذى ينهى .عبدا إذاصلى.... }
$$

\footnotetext{
${ }^{19}$ Aisyah AR, At-Tafsir al-Bayany li al-Quran al-karim, 25.

${ }^{20}$ Aisyah AR, At-Tafsir al-Bayany li al-Quran al-karim.

21 يخبر نعالى عن الإنسان أنه ذو فرح وأشر وبطر وطغيان إذا رأى نفسه قد استغنى وكثر ماله وتو عده وو عظه Dapat dilihat
} dalam, Ismail bin Umar bin Katsir ad-Damasyqy abu al-Fida', Tafsir Quran 'Adzhim (Beirut: Dar Fikr, 1401 H), 259.

$$
\text { وقوله إن الإنسان ليطغى أن رآه استغنى يقول إن الإنسان ليتجاوز حده ويستكبر على ربه فيكفر به لأن رأى نفسه استغنت } 22 \text { ألهان }
$$
Muhammad bin Jarir bin Yazid bin Khalid Ath-thabary Abu ja'far, Jami'u al-Bayan'an ta'wil Ai al-Qur'an (Beirut: Dar Fikir 1405 H) 253.

\footnotetext{
${ }^{23}$ Aisyah AR, At-Tafsir al-Bayany li al-Quran al-karim, 25-16.

${ }^{24}$ Aisyah AR, At-Tafsir al-Bayany li al-Quran al-karim.
} 
Setelah beliau menjelaskan sebab turun ayat, beliau memaparkan: ayat tersebut turun sesudah periode Nabi Muhammad dakwah secara terbuka. Hal ini bisa ditinjau dari sikap orang Quraisy mendustakaan Nabi Muhammad terkait shalat. ${ }^{25}$

Binty Syati mengambil argumentasi Fakhruddin ar-Razy mengenai ayat itu: ar-Razi fokus dengan dua poin, yakni:

Pertama: Lima ayat pertama pada surah al-Alaq tersebut turun sebagai wahyu pertama kepada Nabi Muhammad. Sedangkan bagian lain ayat tersebut diturunkan mengenai Abu Jahal tentang sanggahan mengenai perilakunya yang lalu Rasulullah disuruh menghimpunnya dalam satu surah.

Kedua, baiknya ayat di atas dimengerti berdasarkan pengertian general seperti konteks kalimatnya. Manusia diciptakan Tuhan secara berasal dari darah lalu Tuhan memberi nikmat berupa kekuatan menjadi khalifah di bumi. Tapi pada gilirannya manusia tak melaksanakan tugasnya.

Binty Syati berkomentar atas pendapat ar-Razi. Ia berkata: Dua sisi yang disuguhkan Ar-razi merupakan hal yang bisa dimengerti. Ayat tersebut Allah turunkan mengenai persoalan dakwah Nabi Muhammad yang ditolak oleh sebagian kaumnya. Terlepas dari itu, tak ada larangan untuk memposisikan ayat tersebut atas general redaksinya terlepas dari sebab turun ayat yang mengelilinginya.. ${ }^{26}$

\section{Kesimpulan}

Ada beberapa poin yang dapat ditarik dari penjabaran penulis di atas: Digandengnya redaksi إقرا dengan asma Allah mengindikasikan jika porses pembelajaran hamba-Nya sebaiknya tetap di bawah naungan asma-Nya.

Manusia mesti sadar bagaimanapun umat-Nya berasal dari segumpal darah. Darah merupakan hal yang hina serta rendah derajatnya. Karenanya manusia tidak pantas merasa sombong di dunia.

Tuhan yang menghadirkan manusia di bumi ialah Tuhan yang maha mulia. Di dalam Al-Qur'an redaksi الأكرم ditampilkan sekali saja menggunakan isim tafdhil serta ma'rifah. Ini menjelaskan jika Cuma Allah saja yang mempunyai kemuliaan itu.

Allah menyediakan jalan pada manusia agar mereka tahu beragam hal. Karenanya Allah menegaskan bahwa Ialah yang mengajarkan manusia.

\footnotetext{
${ }^{25}$ Aisyah AR, At-Tafsir al-Bayany li al-Quran al-karim, 27.

${ }^{26}$ Aisyah AR, At-Tafsir al-Bayany li al-Quran al-karim.
} 
Hamka Hasan

\section{DAFTAR PUSTAKA}

Abdillah, Muhammad bin Ahmad bin Abi Bakar bin Farh al-Qurtuby Abu. Al-Jami' li Ahkam al-Quran. Kairo: Dar sya'by, $1372 \mathrm{H}$.

Boullata, Issa J. "Modern Quran Exegesis: A Study of Bint al-Shati' Method." The Muslim Word 64, no. 2 (1974).

Al-Fida', Ismail bin Umar bin Katsir ad-Damasyqy Abu. Tafsir Quran 'Adzhim. Beirut: Dar Fikr, $1401 \mathrm{H}$.

Ja'far, Muhammad bin Jarir bin Yazid bin Khalid Ath-thabary Abu. Jami'u al-Bayan'an ta'wil Ai al-Qur'an. Beirut: Dar Fikir $1405 \mathrm{H}$.

Jansen, J.J.G. Diskursus Tafsir al-Qur'an Modern. Yogyakarta: Tiara Wacana Yogya, 1997.

Sa'ud, Muhammad bin Muhammad Al-Amady Abu. Dar Ihya Turats Al-Araby. Beiruit: t.p., t.t..

Setiawan, Nur Kholis. Al-Qur'an: Ktab Sastra Terbesar. Yogyakarta: eLSAQ Press, 2005. Ats-Tsa'aly, Abd. Rahman bin Muhammad bin Makhluf. Mu'asash al'Aly. Beirut: t.p, t.t.. Yusron, dkk. Studi Kitab Tafsir Kontemporer. Yogyakarta: Teras, 2006).

Al-Zamakhsyari, Abu al-Qasim Mahmud. al-Kassyaf 'an Haqaiq al-Tanzil wa Uyun alAqawil. t.tp: tp, 1997. 